Original scientific paper - Izvorni znanstveni rad

UDK: 637.112 .2

\title{
Fatty acid profile, somatic cell count and microbiological quality of total machine milk and hand stripped milk of Chios ewes
}

doi: $10.15567 /$ mljekarstvo.2017.0207

\author{
Basil Skapetas $^{1 *}$, Vassileios Bampidis ${ }^{1}$, Vladimiros Christodoulou², Maria Kalaitzidou ${ }^{1}$ \\ ${ }^{1}$ Alexander Technological Educational Institute, School of Agricultural Technology, \\ Department of Agricultural Technologists, 57400 Thessaloniki, Greece \\ ${ }^{2}$ Agricultural Research Foundation (N.AG.RE.F.), Animal Research Institute, \\ National, 58100 Giannitsa, Greece
}

Received - Prispjelo: 15.06.2016. Accepted - Prihvaćeno: 06.04.2017.

\begin{abstract}
The objective of this work was to evaluate the effect of milk fraction on composition, fatty acid profile, somatic cell count and microbiological quality of the milk of Chios ewes sheep breed. Totally forty eight animals were included in the study ( 16 of the first, 16 of the second and 16 of the third and subsequent lactations, respectively). The animals were fed with $1.06 \mathrm{~kg} / \mathrm{ewe} /$ day a concentrate mixture and $0.9 \mathrm{~kg} /$ ewe/day alfalfa hay. Ewes were milked twice a day for 10 weeks in a milking parlor of "Casse" type 1x24 with 12 milking units and a low milk line and air pipeline. All the variables measured were compared by ANOVA using SPSS. The results of the experiment showed that fat percentage in hand stripped milk was higher than in total machine milk, while protein and lactose were found in the same levels. Despite the higher fat concentration in the hand stripped milk the fatty acid profile in two fractions was found to be similar. Only eicosapentaenoic acid (EPA) and docosahexaenoic (DHA) acid concentrations were found in higher levels in hand stripped milk. Somatic cell count was lower in total machine milk, while microbiological quality was found to be better in hand stripped milk. Lactation stage influenced significantly all measured variables.
\end{abstract}

Key words: Chios ewes, fatty acid profile, milk fractions, milk composition

\section{Introduction}

Sheep industry in Greece has an important position in agriculture contributing with $30 \%$ to the total output of country's animal production. Meanwhile, Greek local sheep breeds are characterized by unsatisfactory milkability (Skapetas, 1999; Laga et al., 2007). In these breeds, during the machine milking, the hand stripped milk ranges from 16 to $25 \%$, while the machine stripped milk from 15 to $20 \%$ (Skapetas, 2001).

There are some anatomical and physiological characteristics of animals udder that increase the stripped milk fractions (Labussiére, 1988; Bruckmaier and Blum, 1998). In these conditions many farmers are obliged to apply the full milking routine during the machine milking in order to increase the quantity and improve the quality of produced milk. But in these conditions milking parlors' throughput is decreased.

Milk fat is an important component contributing to the processing attributes and organoleptic properties of milk and dairy products from ruminants (Palmquist et al., 1994; McKusick at al., 2002; Chilliard and Ferlay, 2004). Milk fat is the most variable component of milk, both in concentration and composition. In ruminants, the concentration and composition of milk fat are influenced significantly by the diet (Palmquist, 2006; Addis et al., 2005). Meanwhile, other factors such as

*Corresponding author/Dopisni autor: E-mail: vskapetas@gmail.com 
breed, lactation stage, parity, and month of lambing are influencing, also, sheep milk fat concentration (Skapetas et al., 2001).

Between the cisternal and alveolar milk there is a significant difference regarding fat content in sheep (Labussiére, 1988; McKusick et al., 2002). On the other hand, there is a limited information about the fatty acid composition of milk fat in different milk fractions during the machine milking. Milk fatty acids have a dual origin. They are either taken up from plasma lipoproteins (60 \% of the fatty acids secreted in milk), or they are synthesized de novo in the mammary gland from acetate and 3-hydroxybutyrate (Chilliard and Ferlay, 2004). Among the factors that are found to effect the fatty acid profile of ewe's milk, except the diet, are lactation stage, flock, day of testing, ewe age and season (Tsiplakou et al., 2008; De La Fuente et al., 2009; Signorelli et al., 2008).

Sheep milk protein and lactose are more stable and generally are unaffected by milk fraction during machine milking (McKusick at al., 2002). This can be explained by the evolutionary adaptation of mammals to be able to provide milk which is consistent in protein and lactose content regardless different factors (Cowie and Tindal, 1971). Meanwhile, Lane et al. (1969) and Ontsouka et al. (2003) have found in cows lower levels of protein and lactose in milk removed after the injection of oxytocin than in the samples taken during normal milking. Milk lactose percentage, can serve as a marker for inflammation and deterioration in milk clotting parameters. It was found in cows, in ewes and in goats, that reduction of lactose content to about $4 \%$ characterized milk that would not coagulate and, therefore, would be of no value for cheese production (Leitner et al., 2011).

Milk somatic cell count (SCC) and bacteriological quality (CFU) of milk influence also milk cheese making abilities and products' quality in sheep and cattle industry (Pirisi et al., 2000; Sarikaya et al., 2006; Bornem an and Ingh am, 2014). SCC in sheep milk has become an important quality index (Pirisi et al., 2000). The SCC is significantly influenced by intramammary infection (Leitner et al., 2003). Other non-infectious factors like milking frequency, lactation stage, age, breed, nutrition and alterations during the milking (milk fractions) have, also, a moderate influence (Tsipliakou et al., 2008; Signorelli et al., 2008). On the other hand, herd size and farm management practices have, also, significant influence on milk SCC and CFU (Alexopoulos et al., 2011). Gonzalo et al. (2006) have found that milk CFU from flocks milked in milking parlors was lower than milk from flocks that were milked by hand or by bucket system.

The objective of this work was to investigate composition, fatty acid profile, somatic cell count and bacteriological quality in the total machine milk and hand stripped milk in the ewes of Chios breed during the machine milking.

\section{Materials and methods}

\section{Animals and husbandry}

Forty eight Chios breed ewes (16 of the first, 16 of the second and 16 of the third and subsequent lactations) were used to evaluate the effect of milk fraction (total machine milk, hand stripped milk) on milk composition, milk fatty acid profile, SCC and CFU. Simultaneously, the effect of lactation stage, parity and birth type was estimated on the above characteristics. Thirty ewes had twin type births, ten had triple type births, while the remaining animals had single type births.

The experiment was conducted at the Animal Research Institute of the National Agricultural Research Foundation (N.AG.RE.F.), in Giannitsa, Greece, and began on $42 \pm 5$ days postpartum and lasted 24 weeks. All ewes used in the experiment were cared for according to applicable recommendations of the U.S. National Research Council (1996). Ewes were allocated at weaning, on day 42 after parturition, according to their parity into three treatments (P1, first parity; P2, second parity; and P3, third and subsequent parity) of 16 ewes each and accommodated in one floor pen/treatment. All pens were essentially identical, with the same direction and orientation, the same covered area ( $3 \mathrm{~m}^{2} /$ ewe), and all were equipped with similar troughs for grain concentrates, hay and water. For a period of 24 weeks, all ewes were offered a concentrate mixture (1.06 kg/ewe/day, DM basis, Table 1) and alfalfa hay $(0.9 \mathrm{~kg} /$ ewe/day, DM basis, Table 1). The diet (concentrate mixture plus alfalfa hay) was formulated to meet nutrient requirements of sheep for lactation (NRC, 1985). There were no daily feed refusals on a pen basis. Ewes had free access to water. 
The concentrate mixture and alfalfa hay were analyzed for DM by drying at $102{ }^{\circ} \mathrm{C}$ for $16 \mathrm{~h}$ in a forced air oven, and for crude protein, crude fat, and ash according to methods 976.06, 920.39, and 942.05, respectively, of AOAC (1990). Neutral detergent fiber (NDFom), and acid detergent fiber (ADFom) were determined according to Van Soest et al. (1991). NDF was analyzed without sodium sulfite or $a$-amylase, and NDF and ADF were expressed without residual ash.

Table 1. Concentrate and alfalfa composition of lactating ewes diet

\begin{tabular}{|c|c|c|}
\hline & Concentrate & $\begin{array}{c}\text { Alfalfa } \\
\text { hay }\end{array}$ \\
\hline \multicolumn{3}{|l|}{$\begin{array}{c}\text { Ingredient composition } \\
(\mathrm{kg} / \text { tonne })\end{array}$} \\
\hline Corn grain, ground & 380 & - \\
\hline Barley grain, ground & 200 & - \\
\hline Wheat grain, ground & 150 & - \\
\hline Soybean meal (435 g/kg CP) & 140 & - \\
\hline Alfalfa meal (220 g/kg CP) & 100 & - \\
\hline Limestone & 8 & - \\
\hline Dicalcium phosphate & 17 & - \\
\hline Salt & 2.5 & - \\
\hline Vitamin-trace mineral premix ${ }^{\mathrm{a}}$ & 2.5 & - \\
\hline \multicolumn{3}{|l|}{$\begin{array}{l}\text { Chemical composition } \\
\text { (g/kg dry matter-DM) }\end{array}$} \\
\hline Dry matter (as fed) & 880 & 900 \\
\hline Crude protein $(\mathrm{CP})$ & 169 & 189 \\
\hline Crude fat & 31 & 33 \\
\hline Neutral detergent fiber(om) & 172 & 500 \\
\hline Acid detergent fiber(om) & 83 & 333 \\
\hline Ash & 37 & 117 \\
\hline Calcium & 11.0 & - \\
\hline Phosphorus & 7.1 & - \\
\hline Sodium & 1.6 & - \\
\hline Sulfur & 2.2 & - \\
\hline $\begin{array}{l}\text { Net energy for lactation } \\
(\mathrm{MJ} / \mathrm{kg} \mathrm{DM})\end{array}$ & 7.91 & - \\
\hline
\end{tabular}

aPremix supplied per $\mathrm{kg}$ of concentrate: 12500 I.U. vitamin A; 1250 I.U. vitamin $\mathrm{D}_{3} ; 30 \mathrm{mg}$ vitamin $\mathrm{E} ; 0.6 \mathrm{mg} \mathrm{Co} ; 2 \mathrm{mg} \mathrm{Cu}$; $0.8 \mathrm{mg}$ I; 75 mg Fe; 100 mg Mg; 80 mg Mn; 0.3 mg Se; 100 mg Zn. ${ }^{\mathrm{b} C o n c e n t r a t e}$ and alfalfa hay were analyzed for dry matter, crude protein, crude fat and ash according to AOAC (1990), and for neutral detergent fiber and acid detergent fiber according to Van Soest et al. (1991). All other values were calculated from NRC values (1985).
During the experimental period, the health status of all ewes was monitored on daily basis.

\section{Milking procedure and data acquisition}

Ewes were milked twice daily at 8:00 and 16:00 h, in a $1 \times 24$ side by side milking parlor of "Casse" type with 12 milking units and a low milk line and air pipeline. The working parameters of the milking machine were: vacuum level $40 \mathrm{kPa}$, pulsation rate 120 pulsations/min and pulsation ratio 50:50. Milk yield and milk fractions (total machine milk and hand stripped milk) were recorded twice daily every 4 weeks. The experiment lasted 20 weeks (five test-day records).

Milk fractions at morning and afternoon milking were recorded as follows:

- machine milk (MM), which is the quantity of milk that was taken after the setting of milking machine teat cups until the cessation of milk flow,

- machine stripped milk (MSM), which is the amount of milk that was taken by udder stripping with hands without removing the teat cups,

- hand stripped milk (HSM), which is the milk amount that was taken by udder stripping after the removal of teat cups.

Based on the above measures were also calculated:

- total machine milk (TMM = MM + MSM),

- milk yield (MY = TMM + HSM).

During each milk recording from both morning and afternoon milking and from each experimental ewe milk samples were taken, separately, for the total machine milk and from hand stripped milk ( $\sim 60 \mathrm{~mL}$ from each fraction) for milk fat, protein, lactose, SCC, CFU and fatty acid profile determination. Sodium azide $\left(\mathrm{NaN}_{3}\right)$ was used as a preservative of milk samples. Milk samples for SCC and CFU were collected in sterile sample containers.

Milk composition, fatty acid profile, SCC and CFU were examined for the morning and afternoon pooled milk samples.

\section{Chemical analyses}

Milk sample analyses were performed at the Milk Laboratory of the Greek Dairy Organization. Milk fat, protein and lactose contents were measured by near infrared spectrophotometer using a Milkoscan 
FT 120 (Foss Electric, Denmark). The determination of milk SCC was done by a Fossomatic 400, while milk CFU by a Bactoscan 8000S. All instruments were calibrated with sheep milk standards.

Total lipids were extracted with a cold mixture of chloroform and methanol (2:1, v/v) following the method described by Folch et al. (1957). Fatty acids were converted to methyl esters according to the AFNOR method (1984). Fatty acid methyl esters (FAMES) were extracted with $6 \mathrm{ml}$ of hexane using vortex. The separated hexane layer was dried with the addition of anhydrous sodium sulphate (2-3 g) 2 $\mathrm{h}$ and filtered. The residue was washed twice with $2 \mathrm{~mL}$ hexane, dried in rotary evaporator then re-dissolved in $2 \mathrm{ml}$ hexane.

The resulting FAMES were analyzed by using a gas chromatograph consisted of an SSI liquid chromatography pump (model 300; Scientific Systems Inc., State College, PA) equipped with an SSI pulse damper (model LP-21 LO pulse) and a UV-Vis detector (SPD-10AV; Shimadzu Co., Kyoto, Japan). A Hewlett-Packard, Model HP 3396 Series II electronic integrator (Avondale, PA) was used for recording and quantifying the chromatographic peaks.

\section{Statistical analysis}

All the parameters measured were analyzed by ANOVA, using the SPSS Statistical Software Package (1999). The data not presenting Gaussian distribution (SCC and CFU) were normalized by $\log$ transformation. Subsequently, the raw or transformed data were subjected to statistical procedures.

Multiple mean comparisons were made using Duncan's multiple range tests in order to classify the effect of milk fraction, lactation stage, parity and birth type on milk composition, fatty acid profile, SCC and CFU. Differences were considered at a significance level of $\mathrm{P}<0.05$. The weeks were treated as different blocks.

\section{Results and discussion}

Means and standard errors (S.E.) of TMM and HSM are presented in Table 2. HSM constituted the $17.99 \%$ of daily milk yield $(1147 \pm 31.02 \mathrm{~mL})$, while TMM $82.01 \%$. The two milk fractions were significantly influenced by the stage of lactation $(\mathrm{P}<0.001)$.

Table 2. Milk fractions during the machine milking of Chios breed*

\begin{tabular}{ccccc}
\hline & Mean \pm s.e. & \multicolumn{3}{c}{ Significance } \\
\cline { 3 - 4 } & & Lactation stage & Parity & Birthtype \\
\hline TMM (mL/day) & $940.10 \pm 25.64$ & $* * *$ & $*$ & $*$ \\
\hline HSM (mL/day) & $206.33 \pm 7.78$ & $* * *$ & $*$ & NS \\
\hline MY (mL/day) & $1147 \pm 31.02$ & $* * *$ & $*$ \\
\hline${ }^{*}$ s.e. $=$ standard error; TMM $=$ Total machine milk; HSM $=$ Hand stripped milk; MY = Milk yield. NS $=$ Not significant; $\mathrm{P}<0.001$.
\end{tabular}

Table 3: Milk composition, milk somatic cell count and milk bacterial count of Chios sheep breed

\begin{tabular}{|c|c|c|c|c|c|c|}
\hline \multirow[b]{2}{*}{ Variable } & \multirow[b]{2}{*}{$\begin{array}{c}\mathrm{TMM}^{*} \\
\text { (Mean } \pm \text { s.e.) }\end{array}$} & \multirow[b]{2}{*}{$\begin{array}{c}\text { HSM } \\
\text { (Mean } \pm \text { s.e.) }\end{array}$} & \multicolumn{4}{|c|}{ Significance } \\
\hline & & & $\begin{array}{c}\text { Milk } \\
\text { fraction }\end{array}$ & $\begin{array}{l}\text { Lactation } \\
\text { stage }\end{array}$ & Parity & $\begin{array}{l}\text { Birth } \\
\text { type }\end{array}$ \\
\hline Fat $(\%)$ & $6.25 \pm 0.05^{\mathrm{a}}$ & $7.1 \pm 0.06^{\mathrm{b}}$ & $* * *$ & $* * *$ & NS & NS \\
\hline Protein (\%) & $5.73 \pm 0.04^{a}$ & $5.67 \pm 0.03^{\mathrm{a}}$ & NS & $* * *$ & NS & NS \\
\hline Lactose (\%) & $4.71 \pm 0.02^{\mathrm{a}}$ & $4.69 \pm 0.02^{\mathrm{a}}$ & NS & $* * *$ & NS & NS \\
\hline $\operatorname{SCC}(x 1000 / m L)$ & $313 \pm 21^{\mathrm{a}}$ & $573 \pm 7^{b}$ & $* * *$ & $* *$ & NS & NS \\
\hline Log SCC & $5.31 \pm 0.02^{\mathrm{a}}$ & $5.46 \pm 0.02^{\mathrm{b}}$ & $* * *$ & $* * *$ & NS & NS \\
\hline CFU ( x 1000/mL) & $494 \pm 30^{a}$ & $97 \pm 1^{b}$ & $* * *$ & $* * *$ & NS & NS \\
\hline Log CFU & $5.50 \pm 0.03^{\mathrm{a}}$ & $4.75 \pm 0.03^{b}$ & $* * *$ & $* * *$ & NS & NS \\
\hline
\end{tabular}

*s.e. = standard error; TMM = Total machine milk; HSM = Hand stripped milk; SCC = Somatic cell counts;

$\mathrm{CFU}=$ Colony forming units.

abcWithin lines, means not sharing a common superscript differ significantly $(\mathrm{P}<0.05)$. NS $=$ not significant; ${ }^{* * *} \mathrm{P}<0.001$. 
Fat, protein and lactose percentages (means and standard errors) in HSM and TMM are presented in Table 3. As it was expected fat percentage in the HSM was found to be $13.6 \%$ higher than that in the TMM $(\mathrm{P}<0.001)$. This is because fat concentration increased continuously from cisternal to alveolar fraction and increased further in the residual fraction in cows (Ontsouka et al., 2003) and in sheep (Skapetas et al., 2001; McKusick et al., 2002).

As it is known fat has a lower specific gravity than water, fat droplets during milking move less rapidly than the milk aqueous phase and are influenced by capillary and adhesive forces (Ontsouka et al., 2003). This phenomenon underlines the necessity of normal functioning of milk letdown reflex in order to take milk with higher total solids.
On the other hand, protein percentages in the HSM were found relatively lower than that in the TMM, but the differences were not significant. This indicates that casein micelles pass more freely from the alveoli to the udder cistern between milkings compared with the fat globules (McKusick et al., 2002). It can be said that proteins are less dependent from the milk letdown reflex for their removal from the mammary gland. The above findings agree with observations of Ontsouka et al. (2003) and Ayadi et al. (2004) in cows and McKusick et al. (2002) in sheep. Lactose percentages in HSM haven't significant difference with those in TMM. Fat, protein and lactose percentages of ewes milk was affected significantly by the lactation stage.

Table 4. Fatty acid profile in milk fractions of Chios sheep

\begin{tabular}{|c|c|c|c|c|c|c|}
\hline \multirow{2}{*}{$\begin{array}{c}\text { Fatty acid } \\
(\mathrm{mg} / \mathrm{l} 00 \mathrm{mg} \text { of FAME) }\end{array}$} & \multirow{2}{*}{$\begin{array}{c}\text { TMM } \\
\text { (Mean) }\end{array}$} & \multirow{2}{*}{$\begin{array}{l}\text { HSM } \\
\text { (Mean) }\end{array}$} & \multicolumn{4}{|c|}{ Significance } \\
\hline & & & Milk fraction & Lactation stage & Parity & Birth type \\
\hline $\mathrm{C} 4: 0$ & 2.76 & 2.80 & NS & $* * *$ & NS & NS \\
\hline C6:0 & 3.03 & 3.05 & NS & $* * *$ & NS & NS \\
\hline C8:0 & 9.38 & 9.33 & NS & $* * *$ & NS & $*$ \\
\hline C10:0 & 0.36 & 0.37 & NS & $* * *$ & NS & NS \\
\hline $\mathrm{Cl} 2: 0$ & 4.64 & 4.60 & NS & $* * *$ & NS & $*$ \\
\hline Cl4:0 & 12.17 & 12.07 & NS & $* * *$ & NS & NS \\
\hline $\mathrm{C} 14: \ln 5$ & 0.67 & 0.66 & NS & $* * *$ & NS & NS \\
\hline C16:0 & 28.40 & 28.46 & NS & $* * *$ & NS & NS \\
\hline $\mathrm{C} 16: \ln 7$ & 0.94 & 0.94 & NS & $* * *$ & NS & NS \\
\hline C18:0 & 8.41 & 8.41 & NS & $* * *$ & NS & NS \\
\hline $\mathrm{C} 18: \ln 9 \mathrm{t}$ & 1.55 & 1.62 & NS & $* * *$ & NS & NS \\
\hline $\mathrm{Cl} 18 \mathrm{ln} 9 \mathrm{c}$ & 17.46 & 17.51 & NS & $* * *$ & NS & NS \\
\hline $\mathrm{Cl} 8: \ln 7 \mathrm{c}$ cis & 1.70 & 1.77 & NS & $* * *$ & $* *$ & NS \\
\hline $\mathrm{Cl} 18 \mathrm{2n} 6 \mathrm{c}$ & 2.98 & 3.03 & NS & $* * *$ & $* * *$ & $* *$ \\
\hline $\mathrm{C} 18: 3 \mathrm{n} 6$ & 0.25 & 0.25 & NS & $* * *$ & NS & NS \\
\hline $\mathrm{Cl} 18: 3 \mathrm{n} 3 \mathrm{c}$ & 0.30 & 0.29 & NS & $* * *$ & NS & NS \\
\hline CLA c9, t11 & 0.61 & 0.63 & NS & $* * *$ & $* * *$ & NS \\
\hline CLA t10, c12 & 0.06 & 0.06 & NS & $* * *$ & NS & NS \\
\hline CLA c9, cll & 0.05 & 0.045 & NS & $* * *$ & NS & NS \\
\hline C20:0 & 0.22 & 0.21 & NS & $* * *$ & NS & NS \\
\hline C20:5n3c (EPA) & $0.06^{\mathrm{a}}$ & $0.09^{\mathrm{b}}$ & $* * *$ & $* * *$ & NS & NS \\
\hline C22:5n3 & 0.14 & 0.13 & NS & $* * *$ & NS & NS \\
\hline C22:6n3c (DHA) & $0.04^{a}$ & $0.07^{\mathrm{b}}$ & $* *$ & $* * *$ & NS & NS \\
\hline
\end{tabular}

${ }^{*} \mathrm{TMM}=$ Total machine milk; HSM = Hand stripped milk; FAME = Fatty acid methyl esters; CLA = Conjugated linoleic acid; $\mathrm{EPA}=$ Eicosapentaenoic acid $; \mathrm{DHA}=$ Docosahexaenoic acid

abcWithin lines, means not sharing a common superscript differ significantly $(\mathrm{P}<0.05)$.

NS = not significant; ${ }^{* * *} \mathrm{P}<0.001$. 
Tables 4 and 5 summarize data on the fatty acid profile in TMM and HSM.

Although the fat content in the HSM was found significantly higher than in the TMM, in general fatty acid profile of TMM and HSM was similar with the exception of EPA and DHA. EPA in HSM was found to be $50 \%$ higher $(\mathrm{P}<0.001)$, while DHA was found $75 \%$ higher $(\mathrm{P}<0.01)$ in comparison of TMM. One possible explanation for the elevation of EPA and DHA in hand stripped milk is that the body's pool size of these fatty acids is small, except for the large content of DHA in the brain, which is an isolated compartment. EPA and DHA as prostaglandin precursors and membrane constituents are possibly not as readily utilized for energy sources as are other fatty acids (Francois et al., 1998). Also Francois et al. (1998) have found a delay in peak values of EPA and DHA, compared with other milk fatty acids in human milk. These changes in FA secretions are associated in mammary tissue with a joint down-regulation of mammary lipogenic enzyme gene expression (stearoyl-CoA desaturase and FA synthase) and expression of the regulatory element binding transcription factor (SREBF1) (Angulo et al., 2012).

All the fatty acids were significantly influenced by the ewes' lactation stage $(P<0.001)$. Lactation stage have influenced significantly milk fatty acid profile and in cows (Frelich et al., 2009, Bilal et al., 2014) and goats (Ataşoğlu et al., 2009).
All the indices of fatty acid profile of ewes' milk fractions (TMM, HSM) were found to be similar in the two milk fractions. Lactation stage has influenced significantly all the indices of milk fatty acid profile in both fractions $(\mathrm{P}<0.001)$.

Gómez - Cortès et al. (2011) have found in Churra ewes similar fatty acid profile in available and residual milk despite the significant differences in fat content between the above two milk fractions. Also the same authors have found relatively greater values for EPA and DHA in residual milk than in available milk, but the differences were not significant. Similar fatty acid profile between foremilk and residual milk in cows was found by Kernohan et al. (1971). On the other hand Dill et al. (1974) have found that fatty acid profile of bovine milk was not influenced significantly by prolonged influence of oxytocin.

Means and standard errors (S.E.) of milk SCC, $\log$ SCC, CFU and log CFU are presented in Table 3. SCC in the TMM was found $313 \times 10^{3}$ cells $/ \mathrm{mL}$, while in the HSM $573 \times 10^{3}$ cells $/ \mathrm{mL}$. Log SCC in the HSM was found to be $2.82 \%$ higher than that in the TMM $(\mathrm{P}<0.001)$. In general, the results obtained by ANOVA using logarithmic transformation of SCC gave results that are similar to those of the untransformed variable, although statistical significance of the differences was, in some cases, somewhat lower.

Table 5: Indices of fatty acid profile in milk fractions of Chios sheep

\begin{tabular}{|c|c|c|c|c|c|c|}
\hline \multirow{2}{*}{$\begin{array}{c}\text { Fatty acid } \\
(\mathrm{mg} / 100 \mathrm{mg} \text { of FAME) }\end{array}$} & \multirow{2}{*}{$\begin{array}{l}\text { TMM } \\
\text { (Mean) }\end{array}$} & \multirow{2}{*}{$\begin{array}{l}\text { HSM } \\
\text { (Mean) }\end{array}$} & \multicolumn{4}{|c|}{ Significance } \\
\hline & & & Milk fraction & Lactation stage & Parity & Birth type \\
\hline MUFA (\%) & 22.94 & 22.94 & NS & $* * *$ & NS & NS \\
\hline PUFA (\%) & 5.67 & 5.62 & NS & $* * *$ & $*$ & $*$ \\
\hline n6 (\%) & 4.17 & 4.15 & NS & $* * *$ & $* *$ & $*$ \\
\hline n3 (\%) & 0.59 & 0.54 & NS & $* * *$ & NS & NS \\
\hline n6/n3 & 7.15 & 7.31 & NS & $* * *$ & NS & NS \\
\hline SFA (\%) & 71.39 & 71.44 & NS & $* * *$ & NS & NS \\
\hline USFA (\%) & 27.93 & 27.79 & NS & $* * *$ & NS & NS \\
\hline USFA/SFA & 0.35 & 0.35 & NS & $* * *$ & NS & NS \\
\hline CLA (\%) & 0.73 & 0.74 & NS & $* * *$ & NS & NS \\
\hline$\Delta^{9}$ - desatur. index & 28.01 & 27.97 & NS & $* * *$ & NS & NS \\
\hline
\end{tabular}

${ }^{*} \mathrm{TMM}=$ Total machine milk; HSM = Hand stripped milk; MUFA = Monounsaturated fatty acids; PUFA = Polyunsaturated fatty acids; SFA = Saturated fatty acids; USFA = Unsaturated fatty acids; CLA = Conjugated linoleic acid (c-9, t-11 + t-10, c-12 + c-9,c-11).

abcWithin lines, means not sharing a common superscript differ significantly $(\mathrm{P}<0.05)$.

$\mathrm{NS}=$ not significant; ${ }^{*} \mathrm{P}<0.05 ;{ }^{*} \mathrm{P}<0.01 ;{ }^{* *} \mathrm{P}<0.001$. 
Our results are in accordance with those of Gonzalo et al. (1993) and McKusick et al. (2002) in sheep and Skapetas et al. (2009) in goats.

The differences can be explained by the fact that leucocytes in the mammary gland and also particles of the udder epithelial cells have lower specific gravity in comparison of the milk aqueous phase (Sarikaya, et al., 2006). Generally, the SCC in sheep and goats results in higher levels in comparison of those in cows, because the existence of only two mammary glands (dilution effect) and also the influence of the infection reflected by SCC in the animal level is relatively high in sheep and goats (Leitner et al., 2011).

Milk CFU in the HSM $\left(97 \times 10^{3} \mathrm{CFU} / \mathrm{mL}\right)$ was found 4.1 times lower than that in the TMM (494 x 103 CFU/mL, P<0.001), while log CFU was $15.79 \%$ lower in HSM than in TTM $(\mathrm{P}<0.001)$. Like in the case of SCC the differences between fractions were significant for both log CFU and untransformed CFU. The higher milk CFU in the cisternal milk, in the healthy ewes, comparatively with that in alveolar milk can be explained by the fact that microbes colonize first the udder's teat end and enter in the udder cistern through teat canal.

Lactation stage had a significant effect on both SCC and CFU of ewes milk (Table 3).

\section{Conclusion}

The results of this study showed that hand stripped milk in Chios ewes constitutes about $18 \%$ of the total daily milk yield. Milk fat content in this fraction was found significantly higher than that in the total machine milk. Nevertheless, the fatty acid profile in the two milk fractions was similar with the exception of EPA and DHA that were found at higher levels in the hand stripped milk. Milk SCC in the HSM was higher, while milk CFU lower in comparison of TMM. Lactation stage influenced significantly milk fractions, milk yield, fat, fatty acid profile, SCC and CFU. As a general conclusion hand stripping suppression in Chios ewes might significantly affect milk yield, milk fat content and milk bacteriological quality, but not milk fatty acid profile.

\section{Acknowledgements}

This research has been financed by the Research Committee of Alexander Technological Educational Institution of Thessaloniki, Greece. The authors thank the staff of Animal Research Institute, N.AG. RE.F. (Giannitsa, Greece) for help provided during this study.

\section{Profil masnih kiselina, broj somatskih stanica i mikrobiološka kvaliteta mlijeka dobivenog potpunom strojnom mužnjom $i$ ručnim izmuzivanjem Chios ovaca}

\section{Sažetak}

Ciljevi ovog rada bili su procijeniti učinak izmuzivanja mlijeka na sastav, profil masnih kiselina, broj somatskih stanica i mikrobiološku kvalitetu mlijeka ovaca Chios pasmine. U istraživanje je bilo uključeno ukupno četrdeset osam životinja (16 prve, 16 druge i 16 treće i kasnijih laktacija). Sve su životinje hranjene sa 1,06 kg/ovci/dan koncentrirane smjese i $0,9 \mathrm{~kg} /$ ovci/dan sijena lucerne. Ovce su mužene dva puta dnevno tijekom 10 tjedana u izmuzištu tipa "Casse» 1x24 s 12 muznih jedinica. Dobiveni podaci analizirani su ANOVA testom. Rezultati istraživanja pokazali su da je udjel masti ručno izmuženog mlijeka bio veći nego u mlijeku dobivenom cjelokupnom strojnom mužnjom, dok su udjeli proteina i laktoze bili na istim razinama. Unatoč višem udjelu masti u ručno izmuženom mlijeku, profil masnih kiselina u dvije frakcije bio je sličan. Samo su koncentracije eikozapentaenske kiseline (EPA) i dokoheksanoične kiseline (DHA) utvrđene $u$ većim količinama u ručno izmuženom mlijeku. Broj somatskih stanica bio je niži u cjelokupnoj strojnoj mužnji, a mikrobiološka kvaliteta bila je bolja u ručno izmuženom mlijeku. Faza laktacije značajno je utjecala na sve izmjerene varijable.

\footnotetext{
Ključne riječi: Chios ovce, profil masnih kiselina, frakcije mlijeka, sastav mlijeka
} 


\section{References}

1. Addis, M., Cabiddu A., Pina, G., Decandia, M., Piredda, G., Pirisi, A. (2005): Milk and cheese fatty acid composition in sheep fed mediterranean forages with reference to conjugated linoleic acid cis-9, trans-11. Journal of Dairy Science 88, 3443-3454. https://doi.org/10.3168/jds.S0022-0302(05)73028-9

2. AFNOR (1984): Butique AFNOR Edition, ISO 233.

3. Alexopoulos, A., Tzatzimakis, G., Bezirtzoglou, E., Plessas, S., Stavropoulou, E., Sinapis, E., Abas, Z. (2011): Microbiological quality and related factors of sheep milk produced in farms of NE Greece. Anaerobe 17 (6), 276-279. https://doi.org/10.1016/j.anaerobe.2011.03.011

4. Angulo, J., Mahecha, L., Nurnberg, K., Nurnberg, G., Dannenberger, D., Olivera, M., Boutinaud, M., Leroux, C., Albrecht, E., Bernard, L. (2012): Effects of polyunsaturated fatty acids from plant oils and algae on milk fat yield and composition are associated with mammary lipogenicand SREBF1 gene expression. Animal 6, 1961-1972. https://doi.org/10.1017/S1751731112000845

5. Association of Official Analytical Chemists (AOAC) (1990): Official Methods of Analysis, AOAC. Helrich, K. (Ed), $15^{\text {th }}$ ed. Arlington, VA, USA.

6. Ataşoğlu, C., Uysal-Pala, H., Karagól-Yáceer, Y. (2009): Changes in milk fatty acid composition of goats during lactation in a semi-intensive production system. ArchivTierzucht 52 (6), 627-636,

7. Ayadi, M., Caja, G., Such, X., Rovai, M., Albaneli, E. (2004): Effect of different milking intervals on the composition of cisternal and alveolar milk in dairy cows. Journal Dairy Research 71, 304-310.

8. Bilal, G., Cue, R.I., Mustafa, A. F., Hayes, J.F. (2014): Effects of parity, age at calving and stage of lactation on fatty acid composition of milk in Canadian Holsteins. Canadian Journal of Animal Science 94, 401-410. https://doi.org/10.4141/cjas2013-172

9. Borneman, D.L., Ingham, S. (2014): Correlation between standard plate count and somatic cell count milk quality results for Wisconsin dairy producers. Journal of Dairy Science 97, 2646-2652.

10. Bruckmaier, R.M., Blum, J.U. (1998): Oxytocine release and milk removal in ruminants. Journal of Dairy Science 81, 939-949. https://doi.org/10.3168/jds.S0022-0302(98)75654-1

11. Chilliard, Y., Ferlay, A. (2004): Dietary lipids and forages interaction on cow and goat milk fatty acids composition and sensory properties. Reproduction, Nutrition, Development 44, 467-492. https://doi.org/10.1051/rnd:2004052

12. Cowie, A.T., Tindal, S.J. (1971): The physiology of lactation. Camelot Press Ltd., London.

13. De La Fuente, L.F., Barbosa, E., Carriedo, JA., Gonzalo, C., Arenas, R., Fresno, J.M., San Primitivo, F. (2009): Factors influencing variation of fatty acid content in ovine milk. Journal of Dairy Science 92, 3791-3799. https://doi.org/10.3168/jds.2009-2151
14. Dill, C.W., Lane, G.T., Hartsfield, S.N. (1974): Influence of repeated oxytocic treatments on composition of bovine milk fat. Journal of Dairy Science 57, 1164-1169. https://doi.org/10.3168/jds.S0022-0302(74)85031-9

15. Folch, J., Lees, M., Sloane Stanley, G.H. (1957): A simple method for the isolation and purification of total lipids from animal tissues. The Journal of Biological Chemistry 226, 497-509.

16. François, C.A., Connor, S.L., Wander, R.C., Connor, W.E. (1998): Acute effects of dietary fatty acids on the fatty of human milk. The American Journal of Clinical Nutrition 67, 301-308.

17. Frelich, J., Šlachta, M., Hanuš, O., Špička, J., Samková, E. (2009): Fatty acid composition of cow milk fat produced on low-input mountain farms. Czech Journal of Animal Science, 54, 532-539.

18. Gomez-Cortès, P., Bodas, R, Mantecon, A.R., de la Fuente, M.A., Manso, T. (2011): Milk composition and fatty acid profile of residual and available milk from ewes fed with diets supplemented with different vegetable oils. Small Ruminant Research 97, 72-75. https://doi.org/10.1016/j.smallrumres.201 1.01.003

19. Gonzalo, C., Baro, J.A., Carriedo, J.A., San Primitivo, F. (1993): Use of the fossomatic method to determine somatic cell counts in sheep milk. Journal of Dairy Science 76, 115-119. https://doi.org/10.3168/jds.S0022-0302(93)77330-0

20. Gonzalo, C., Carriedo, J. A., Beneitez, E., Juarez, M.T., De La Fuente, L.F., San Primitivo, F. (2006): Short Communication: Bulk tank total bacterial count in dairy sheep: factors of variation and relationship with somatic cell count. Journal of Dairy Science 89, 549-552. https://doi.org/10.3168/jds.S0022-0302(06)72117-8

21. Kernohan, E.A., Wadsworth, J.C., Lascelles, A.K. (1971): Changes in the composition of bovine milk fat during milking. Journal of Dairy Research 38, 65-68. https://doi.org/10.1017/S0022029900013698

22. Labussiére, J. (1988): Review of physiological and anatomical factors influencing the milking ability of ewes and the organization of milking. Livestock Production Science 18, 253-274. https://doi.org/10.1016/0301-6226(88)90035-8

23. Laga, V., Skapetas, B., Katanos, I., Sinapis, E., Hatziminaoglou, I. (2007): Efficiency of milking machines for dairy ewes in Central Macedonia, Greece (In Greek). Animal Science Review 36, 23-40.

24. Lane, G.T., Dill, C.W., Armstrong, B.C., Switzer, L.A. (1969): Influence of repeated oxytocin injections on composition of dairy cows' milk. Journal of Dairy Science 53, 427-429. https://doi.org/10.3168/jds.S0022-0302(70)86224-5

25. Leitner, G., Chaffer, M., Caraso, Y., Ezra, E., Karabea, D., Winkler, M., Glickman, A., Saran, A. (2003): Udder infection and milk somatic cell count, NAGase activity and milk composition - fat, protein and lactose- in Israeli Assaf and Awassi sheep. Small Ruminant Research 49, 157-164. https://doi.org/10.1016/S0921-4488(03)00079-8 
26. Leitner, G., Merin, U., Silanikove, N. (2011): Effects of glandular bacterial infection and stage of lactation on milk clotting parameters: Comparison among cows, goats and sheep. International Dairy Journal 2, 1279-285. https://doi.org/10.1016/j.idairyj.2010.11.013

27. McKusick, B.C, Thomas, D.L, Berger, Y.M, Marnet, P.G. (2002): Effect of milking interval on alveolar versus cisternal milk accumulation and milk production and composition in dairy ewes. Journal of Dairy Science 85, 2197-206. https://doi.org/10.3168/jds.S0022-0302(02)74299-9

28. National Research Council (NRC) (1985): Nutrient Requirements of Sheep. $6^{\text {th }}$ rev. ed. National Academy Press, Washington, DC, USA.

29. National Research Council (NRC) (1996): Guide for the care and use of laboratory animals. National Academy Press, Washington, DC, USA.

30. Ontsouka, C.E., Bruckmaier, R.M., Blum, J.W. (2003): Fractionized milk composition during removal of colostrum and mature milk. Journal Dairy Science 86, 2005-2011. https://doi.org/10.3168/jds.S0022-0302(03)73789-8

31. Palmquist, D.L. (1994): The role of dietary fats in efficiency of ruminants. Journal of Nutrition 24, 1377-1382.

32. Palmquist, D.L. (2006): Milk Fat: Origin of fatty acids and Influence of nutritional factors thereon. Advanced Dairy Chemistry 2, 43-92. https://doi.org/10.1007/0-387-28813-9_2

33. Pirisi, A., Piredda, G., Corona, M., Pes, M., Pintus, S., Ledda, A. (2000): Influence of somatic cell count on ewe's milk composition, cheese yield and cheese quality. Proceedings of the $6^{\text {th }}$ Great Lakes dairy sheep symposium, p. 47-59.

34. Sarikaya, H., Schlamberger, G., Meyer, H.D., Bruckmaier, R.M. (2006): Leukocyte populations and mRNA expression of inflammatory factors in quarter milk fractions at different somatic cell score levels in dairy cows. Journal of Dairy Science 89, 2479-2486. https://doi.org/10.3168/jds.S0022-0302(06)72322-0
35. Signorelli, F., Contarini, G., Annicchiarico, G., Napolitano, F., Orrù, L., Catillo, G., Haenlein, F.W.G., Moioli, B. (2008): Breed differences in sheep milk fatty acid profiles: Opportunities for sustainable use of animal genetic resources. Small Ruminant Research 78, 24-31. https://doi.org/10.1016/j.smallrumres.2008.04.003

36. Skapetas, B. (1999): A study on the productive characteristics and the effects of some nutritional treatments on the productivity of mountainous sheep of Zackel type. PhD thesis. Aristotle University of Thessaloniki, School of Agriculture, Thessaloniki, Greece, pp. 1-178.

37. Skapetas, B., Hatziminaoglou, I., Karalazos, A., Sinapis, I. (2001): A study on the adaptation of the mountain Greek sheep breed to the machine milking (in Greek). Animal Science Review 28, 15-31.

38. Skapetas, B., Sinapis, E., Katanos, I., Laga, V., Poupoulis, C., Mazaraki, K., Aggelopoulos, S. (2009): Milk somatic cell counts, milk bacterial counts and milk composition of local Greek goats. Animal Science Review 39, 59-68.

39. Statistical Package for the Social Sciences (1999): Release 10.0. SPSS Inc., Chicago, IL, USA.

40. Tsiplakou, E., Kominakis, A., Zervas, G. (2008): The interaction between breed and diet on CLA and fatty acids content of milk fat of four sheep breeds kept indoors or at grass. Small Ruminant Research 74, 179-187. https://doi.org/10.1016/j.smallrumres.2007.06.008

41. Van Soest, P.J., Robertson, J.B., Lewis, B.A. (1991): Methods for dietary fiber, neutral detergent fiber, and non starch polysaccharides in relation to animal nutrition. Journal of Dairy Science 74, 3583-3597. https://doi.org/10.3168/jds.S0022-0302(91)78551-2 